\title{
Effects of dietary brown propolis on nutrient intake and digestibility in feedlot lambs
}

\author{
Jonilson Araújo da Silva1, Camila Celeste Brandão Ferreira Ítavo', Luís Carlos Vinhas Ítavo², \\ Maria da Graça Morais ${ }^{1}$, Gumercindo Loriano Franco ${ }^{1}$, Lucia Maria Zeoula ${ }^{3}$, Natália da Silva \\ Heimbach ${ }^{1}$
}

\footnotetext{
${ }^{1}$ Universidade Federal de Mato Grosso do Sul, Campo Grande, MS, Brasil.

2 Universidade Católica Dom Bosco, Campo Grande, MS, Brasil.

${ }^{3}$ Universidade Estadual de Maringá, Maringá, PR, Brasil.
}

\begin{abstract}
The present study tested brown propolis in crude or extract form as a feed supplement for feedlot lambs to identify the type that most improves in vivo nutrient digestibility. Digestibility was assessed by both total fecal collection and internal markers and the results obtained by these techniques were compared. The completely randomized design was used to compare feed intake and nutrient digestibility of 24 male lambs aged seven months among four dietary treatments (crude brown propolis, propolis ethanol extract, monensin sodium, and control). Methods of feces collection were compared using a completely randomized split-plot design, with experimental diets corresponding to the main factor and the methods to estimate fecal production as the sub-factor. The diets had a roughage:concentrate ratio of 50:50, with Tifton- 85 bermudagrass hay (Cynodon spp.) as roughage, and ground corn, soybean meal and minerals as concentrate. The lambs fed diets with crude propolis had higher feed intake than those fed diets containing monensin sodium. The different diets did not affect dry matter, organic matter, crude protein, neutral detergent fiber, or acid detergent fiber digestibility, but crude propolis supplementation provided higher ether extract digestibility than monensin sodium. Nutrient digestibility, as indicated by indigestible neutral detergent fiber, indigestible acid detergent fiber and sequentially-determined indigestible acid detergent fiber, was lower than that found with the fecal collection method. The addition of brown propolis has the same effect as monensin, but neither maximized nutrient availability in the diet of feedlot lambs at 7 months of age. Digestibility assessment using the internal markers indigestible neutral detergent fiber, indigestible acid detergent fiber and sequentially-determined indigestible acid detergent fiber is not an efficient method compared with total feces collection.
\end{abstract}

Key Words: flavonoids, monensin, ruminants

\section{Introduction}

Ionophores inhibit the growth of Gram-positive bacteria, thereby altering short-chain fatty acid concentrations (i.e., increasing propionate and reducing methane production) and improving the energetic efficiency of ruminal fermentation (Nagajara and Taylor, 1987; NRC, 2000). However, the possibility of developing bacterial resistance against ionophores such as monensin is considered a threat to human health in many countries (Ríspoli et al., 2009), and investigations of compounds that can replace ionophores have been carried out.

One alternative to ionophore use for ruminant treatment is propolis administration (Ozturk et al., 2010; Ítavo et al., 2011a). Propolis, which contains flavonoids, phenolic acids,

Received March 25, 2013 and accepted March 14, 2014

Corresponding author: camila.itavo@ufms.br

http://dx.doi.org/10.1590/S1516-35982014000700006

(c) 2014 Sociedade Brasileira de Zootecnia. This is an Open Access article distributed under the terms of the Creative Commons Attribution Non-Commercial License, which permits unrestricted non-commercial use, distribution, and reproduction in any medium, provided the original work is properly cited. esters, phenolic aldehydes and ketones (Fernandes Júnior et al., 2006; Funari and Ferro, 2006), exerts a bacteriostatic activity on Gram-positive and certain Gram-negative bacteria. According to Mirzoeva et al. (1997), propolis likely changes the bionergetic status of bacteria membranes and inhibits their motility, a behavior that resembles the ionophore activity.

Propolis composition is affected by the flower species visited by bees during flowering (Ghisalberti, 1979). Thus, the sensitivity of microorganisms to propolis varies according to the composition and antimicrobial potential of this substance (Choi et al., 2006). In vitro (Stradiotti Jr. et al., 2004a; Stradiotti Jr. et al., 2004b) and in vivo assays (Ítavo et al., 2011a; Ítavo et al., 2011b) have demonstrated the positive effect of including ethanol extract of propolis (EEP) in ruminant diets. Nevertheless, these results are not consistent, likely because the propolis samples tested were not chemically characterized and methodological aspects such as the amount of propolis provided and administration procedures were not standardized (Stelzer et al., 2009). Other studies must therefore be conducted to further investigate this issue. 
The present study evaluated brown propolis, crude or in extract form, as a dietary supplement for feedlot lambs, to identify its effect on in vivo nutrient digestibility in ruminants and the propolis form that best suits to this purpose. To that end, feed intake and nutrient digestibility were determined by total fecal collection and internal markers, and both methods were compared. The results obtained were compared to determine the most reliable method for digestibility assessment.

\section{Material and Methods}

The experiment was carried out at Universidade Federal de Mato Grosso do Sul, Campo Grande, MS, Brazil, between April and June 2010, having been approved by the Ethics Committee for Use of Animal in Experiments (no. 218/2009).

The experiment lasted 56 days and was divided into four 14-day periods. Twenty four castrated Texel crossbred male lambs at 7 months of age and $24.5 \pm 2.9 \mathrm{~kg}$ of body weight were used in this trial. Animals were housed in individual $3 \mathrm{~m}^{2}$ pens provided with a wood lath floor, feeder, and water drinkers. For parasite control, lambs received anthelmintic medication at the beginning of the experiment and underwent parasitic load control using the FEC (fecal egg count per gram) test. When FEC was $\geq 500$, a second anthelmintic dose was administered.

Ground Tifton 85 (Cynodon spp.) hay chopped to $5 \mathrm{~mm}$ length was used as roughage feed at a forage:concentrate ratio of 50:50 on a dry matter (DM) basis (Table 1).

The lambs received one of four dietary treatments consisting of the basal diet without any supplement (control); with addition of $0.1 \mathrm{~g} / \mathrm{kg}$ of DM of crude brown propolis; $15 \mathrm{~mL} / \mathrm{kg}$ of DM of brown propolis extract (Ítavo et al., 2011a); and $31.8 \mathrm{mg} / \mathrm{kg}$ of DM of monensin sodium (NRC, 2007). The additives were included in the diet only

Table 1 - Chemical composition of total basal diet and its components

\begin{tabular}{lccc}
\hline Chemical composition & $\begin{array}{c}\text { Tifton } 85 \\
\text { hay }\end{array}$ & Concentrate & Total diet \\
\hline Dry matter (g/kg) & 924.54 & 896.83 & 910.68 \\
Mineral matter (g/kg DM) & 72.39 & 60.76 & 66.57 \\
Organic matter (g/kg DM) & 927.61 & 939.24 & 933.43 \\
Crude protein (g/kg DM) & 129.94 & 253.53 & 191.73 \\
Neutral detergent fiber (g/kg DM) & 747.75 & 276.30 & 512.02 \\
Acid detergent fiber (g/kg DM) & 401.12 & 109.58 & 255.35 \\
Ether extract (g/kg DM) & 28.77 & 35.69 & 32.23 \\
Total carbohydrates (g/kg DM) & 768.90 & 650.02 & 709.46 \\
Non-fibrous carbohydrates (g/kg DM) & 21.15 & 373.72 & 197.44 \\
\hline${ }^{1}$ Containing 517 g corn meal, 482 g soybean meal and 1 g mineral premix (per kg of \\
dry matter). Premix composition (mg/kg): calcium - 6,300.00; cobalt - 0.30, copper - 3.75; \\
sulfur - 750.00; phosphorus - 4,800.00; iodine - 0.42, manganese - 9.00; selenium - 0.12; \\
sodium - 1,000.00; zinc - 27.00.
\end{tabular}

at feeding time. Propolis extract was sprayed over the feed.

Brown propolis was obtained from an apiary where the bees visited alecrim-do-campo (Baccharis dracunculifolia) and assa-peixe (Vernonia polyanthes) flowers.

Crude propolis was ground in a knife mill with $5-\mathrm{mm}$ mesh sieve. Propolis extract was prepared according to Stradiotti et al. (2004a) by infusing $30 \mathrm{~g}$ of crude propolis in $100 \mathrm{~mL}$ of $70 \mathrm{v} / \mathrm{v}$ ethanol solution (prepared with grain alcohol) for 10 days, followed by supernatant removal. Crude propolis and propolis extract were kept cool $\left(-20^{\circ} \mathrm{C}\right)$ and protected from light.

Crude propolis was analyzed for dry matter (WHO, 1998), ash (WHO, 1998), methanol-insoluble residues (Brasil, 2001), wax (Brasil, 2001), dry residues (methanesoluble solids) (European Pharmacopoeia, 2002), flavonoids (Woisky and Salantino, 1998), and total phenols (AOAC, 1997). Propolis extract was analyzed for concentrations of dry material, flavonoids and phenols content (Table 2). The flavonoids and total phenols were measured by colorimetry with quercetin and gallic acid as standards, respectively.

The animals were fed twice daily $(08.00 \mathrm{~h}$ and $16.00 \mathrm{~h})$, in excess, to allow nearly 50 to $100 \mathrm{~g}$ refusals (orts) $/ \mathrm{kg} \mathrm{DM}$ offered. The leftovers were quantified daily and collected for sampling. Total feces were collected in collection bags for $48 \mathrm{~h}$ on the seventh day of each period, with manual collector emptying before the animals were fed. Feces were homogenized and $100 \mathrm{~g} / \mathrm{kg}$ were separated to form a composite integrate sample.

For indirect determination of fecal production (using internal markers), feces were collected twice daily $(08.00 \mathrm{~h}$ and $16.00 \mathrm{~h}$ ) directly from the rectum of lambs for $48 \mathrm{~h}$ on the same days as total feces collection.

The internal markers evaluated were indigestible neutral detergent fiber (iNDF), indigestible acid detergent fiber (iADF) and sequentially-determined indigestible acid detergent fiber (iADFSeq). These were determined using in situ incubation for $144 \mathrm{~h}$ (Berchielli et al., 2000) in two castrated male bulls with a cannula implanted in the rumen.

Table 2 - Chemical composition of brown propolis in crude and extract form

\begin{tabular}{lcc}
\hline \multirow{2}{*}{ Component } & \multicolumn{2}{c}{ Form } \\
\cline { 2 - 3 } & Crude propolis & Propolis extract \\
\hline Ash (g/kg DM) & 34.5 & - \\
Dry matter (g/kg) & 902.9 & - \\
Methanol-insoluble residue (g/kg DM) & 585.6 & - \\
Wax (g/kg DM) & 95.6 & - \\
Dry residue (g/kg DM) & 307.9 & 79.5 \\
Total phenols (g/kg DR) & 68.1 & 584.9 \\
Total flavonoids (g/kg DR) & 4.6 & 15.0 \\
\hline
\end{tabular}

DM - dry matter; DR - dry residue. 
One gram of feces, feed and leftover samples ground and sieved to $2 \mathrm{~mm}$ size was placed in $5 \times 5 \mathrm{~cm}$ nonwoven fabric bags with $100 \mu \mathrm{m}$ porosity. Fiber content was determined using a Tecnal ${ }^{\circledR}$ TE-149 fiber analyzer (Tecnal, Piracicaba, Brazil). After incubation, the bags were removed from the rumen, washed with water and dried in a forced ventilation oven at $55^{\circ} \mathrm{C}$. Fiber content was determined by submerging the bags in neutral detergent solution (Van Soest et al., 1991) without thermostable amylase and sodium sulfite.

For chemical analyses, feed, leftovers and feces were dried in a forced-ventilation oven at $55{ }^{\circ} \mathrm{C}$ for $96 \mathrm{~h}$ and ground in a knife mill coupled to a $1 \mathrm{~mm}$ mesh screen. Analyses were performed according to AOAC (2000) method 930.15 for dry matter (DM), 932.05 for organic matter (OM), 976.05 for crude protein (CP) and 920.39 for ether extract (EE) determination. Neutral detergent fiber (NDF) and acid detergent fiber (ADF) levels were determined according to Van Soest et al. (1991), without the use of sulfite and thermostable amylase.

To evaluate feed additives, treatments were arranged in a completely randomized design with 6 replicates per treatment. The statistical model used was:

$$
\mathrm{Y}_{i j}=\mu+\mathrm{A}_{i}+\varepsilon_{i j}
$$

in which: $\mathrm{Y}_{i j}=\mathrm{j}$-th observation of additive $i ; \mu=$ overall constant; $\mathrm{A}_{i}=$ additive effect on diet $i$, with $i=1,2,3$, and 4 ; and $\varepsilon_{i j}=$ random error for each observation $\mathrm{Y}_{i j}$. Data were evaluated using analysis of variance and means were compared by Tukey's test at a significance level of 0.05 .

To estimate fecal output, the completely randomized design was subdivided into plots, with experimental diets corresponding to the main factor and the methods to estimate fecal production as the sub-factor. The statistical model used was:

$$
\mathrm{Y}_{i j k}=\mu+\mathrm{A}_{i}+\mathrm{B}_{j}+\mathrm{AB}_{i j}+\varepsilon_{i j k},
$$

in which: $\mathrm{Y}_{i j k}=\mathrm{j}$-th observation of the additive $i ; \mu=$ overall constant; $\mathrm{A}_{i}=$ additive effect on diet $i$, with $I=1$, 2,3 , and $4 ; \mathrm{B}_{j}=$ effect of method $j$, with $j=1,2,3$, and 4 ; $\mathrm{AB}_{i j}=$ interaction between treatment $i$ and method $j$; and $\varepsilon_{i j k}=$ random error for each observation $\mathrm{Y}_{i j k}$. Means were compared using Dunnett's test at a significance level of 0.05 . The method of total feces collection was used for control.

\section{Results}

Nutrient intake and metabolizable energy were higher in lambs fed crude propolis than those receiving monensin sodium. The animals fed diets with propolis extract had intermediate intake, similar to that of lambs fed monensin sodium. Dry matter (g/kg LW), EE, ADF and NDF intakes were not affected by additives.

The additives did not affect DM (0.74), OM (0.76), CP (0.72), NDF (0.66) and ADF (0.61) digestibility and metabolizable energy of the diets (Table 4). However, EE digestibility was higher for animals receiving crude propolis $(0.78)$ than for those receiving dietary monensin sodium (0.68) (Table 4).

A comparison of digestibility assessment methods showed that all internal markers overestimated fecal DM excretion, with values higher than the $548.74 \mathrm{~g} /$ day determined by total feces collection. As a consequence, these internal markers also underestimated nutrient digestibility (Table 5).

\section{Discussion}

Lambs fed diets with crude brown propolis exhibited the highest voluntary DM, metabolizable energy and nutrient intakes, measured as a $\mathrm{g} /$ day and $\mathrm{g} / \mathrm{kg}$ of $\mathrm{LW}^{0.75}$ (Table 3). Ítavo et al. (2011a) found that lambs receiving

\begin{tabular}{|c|c|c|c|c|c|c|}
\hline \multirow{2}{*}{ Intake } & \multicolumn{4}{|c|}{ Diets } & \multirow{2}{*}{ SEM } & \multirow{2}{*}{ P-value } \\
\hline & Crude propolis & Propolis extract & Monensin sodium & Control & & \\
\hline DM (g/day) & $1185.1 \mathrm{a}$ & $1063.6 \mathrm{ab}$ & $943.3 b$ & $1021.4 \mathrm{ab}$ & 68.6 & 0.05 \\
\hline CP (g/day) & $230.9 a$ & $207.5 \mathrm{ab}$ & $181.5 b$ & $200.2 \mathrm{ab}$ & 13.4 & 0.05 \\
\hline MM (g/day) & $77.1 \mathrm{a}$ & $69.0 \mathrm{ab}$ & $60.6 b$ & $65.8 \mathrm{ab}$ & 4.6 & 0.05 \\
\hline OM (g/day) & $1108.0 \mathrm{a}$ & $994.7 \mathrm{ab}$ & $882.7 b$ & $955.6 \mathrm{ab}$ & 64.0 & 0.05 \\
\hline NDF (g/day) & 567.8 & 506.9 & 457.0 & 479.0 & 33.9 & 0.06 \\
\hline ADF (g/day) & 283.0 & 252.4 & 229.3 & 237.2 & 17.0 & 0.07 \\
\hline EE (g/day) & 40.9 & 37.4 & 33.4 & 36.1 & 2.6 & 0.15 \\
\hline DM (g/kg LW) & 40.2 & 369.0 & 33.7 & 36.3 & 0.2 & 0.09 \\
\hline DM (g/kg LW $\left.{ }^{0.75}\right)$ & $93.6 \mathrm{a}$ & $85.4 \mathrm{ab}$ & $77.4 \mathrm{~b}$ & $83.5 \mathrm{ab}$ & 4.3 & 0.04 \\
\hline $\mathrm{NDF}\left(\mathrm{g} / \mathrm{kg} \mathrm{LW} \mathrm{LW}^{0.75}\right)$ & $44.8 \mathrm{a}$ & $40.7 \mathrm{ab}$ & $37.5 b$ & $39.1 \mathrm{ab}$ & 2.1 & 0.04 \\
\hline ME (Mcal/day) & $3.2 \mathrm{a}$ & $2.8 \mathrm{~b}$ & $2.6 b$ & $2.7 \mathrm{~b}$ & 0.1 & 0.01 \\
\hline
\end{tabular}

Table 3 - Mean nutrient intake (and standard error) of feedlot lambs receiving diets with different feed additives

DM - dry matter; OM - organic matter; MM - mineral matter; CP - crude protein; NDF - neutral detergent fiber; ADF - acid detergent fiber; EE - ether extract; ME - metabolizable energy; LW - live weight.

SEM - standard error of the mean.

Means followed by different letters in a row differ statistically by Tukey's test $(\mathrm{P}<0.05)$. 
$15 \mathrm{~mL}$ of green propolis daily had higher feed intake than those receiving monensin. The lower intake observed for the animals fed monensin may be related to a possible reduction in rumen motility (Deswysen et al., 1987), improvement in feed efficiency (Salles et al., 2008), or higher levels of propionate production (Aderinboye et al., 2012). The high flavonoid content in propolis extract, which displays bactericidal activity in the ruminal microorganisms (Aguiar et al., 2013), was the possible cause of the intermediate feed intake for this treatment. In the present study, because crude brown propolis had lower phenol and flavonoid concentrations than brown propolis extract, the highest feed intake by lambs fed diets with crude propolis was likely caused by wax concentration and methanol-insoluble residue (Table 2).

Lambs fed diets with brown propolis extract, however, had the same feed intake as those fed diets containing monensin sodium, corroborating the comparison between brown propolis extract and monensin sodium performed by Ítavo et al. (2011a).

Other studies on ruminants have found no effect of propolis on nutrient intake in cattle fed dietary freeze-dried propolis extract (Prado et al., 2010), dairy cattle receiving a daily dose of $64 \mathrm{~mL}$ of propolis extract (Freitas et al., 2009), or dairy goats receiving $50 \mathrm{v} / \mathrm{v}$ propolis extract (in $70 \mathrm{v} / \mathrm{v}$ alcohol solution) at up to $12.0 \mathrm{~mL} / \mathrm{animal} /$ day or ground crude propolis (Lana et al., 2007). The lower voluntary DM intake of animals receiving monensin corroborates other studies on feedlot lambs (Heydari et al., 2008).

Dry matter digestibility ranged from 0.75 to 0.73 and was not affected by the dietary treatments (Table 4 ). The average DM digestibility (0.74) was higher than the 0.62 observed by Îtavo et al. (2011b) in a metabolic assay involving lambs receiving diets with a 50:50 roughage:concentrate ratio and with inclusion of green propolis extract. This difference may be a result of roughage quality since Tifton-grass hay is better than the brachiaria grass MG5 (Brachiaria brizantha cv. MG5) used by Ítavo et al. (2011b).

Corroborating the present study, Stelzer et al. (2009) found that the daily inclusion of $34 \mathrm{~mL}$ of propolis extract in dairy cattle with a 60:40 roughage:concentrate ratio does not affect the digestibility of DM and other nutrients $(\mathrm{CP}$, EE, NDF, total carbohydrates, non-fibrous carbohydrates).

Despite these results, Prado et al. (2010) recorded a reduction in DM, OM, NDF and ADF digestibility in cattle diets with a 72.5:27.5 roughage:concentrate ratio, with

Table 4 - Mean coefficient of digestibility and metabolizable energy (and standard error) of feedlot lambs receiving diets with different feed additives

\begin{tabular}{|c|c|c|c|c|c|c|}
\hline \multirow{2}{*}{ Parameter } & \multicolumn{4}{|c|}{ Diets } & \multirow{2}{*}{ SEM } & \multirow{2}{*}{ P-value } \\
\hline & Crude propolis & Propolis extract & Monensin sodium & Control & & \\
\hline DMD (0-1) & 0.75 & 0.73 & 0.74 & 0.73 & 1.27 & 0.60 \\
\hline OMD (0-1) & 0.79 & 0.77 & 0.73 & 0.74 & 2.58 & 0.32 \\
\hline CPD $(0-1)$ & 0.81 & 0.78 & 0.76 & 0.76 & 2.32 & 0.32 \\
\hline NDFD $(0-1)$ & 0.71 & 0.65 & 0.65 & 0.63 & 3.75 & 0.27 \\
\hline ADFD (0-1) & 0.67 & 0.62 & 0.58 & 0.57 & 4.18 & 0.24 \\
\hline $\operatorname{EED}(0-1)$ & $0.78 \mathrm{a}$ & $0.74 \mathrm{ab}$ & $0.68 b$ & $0.70 \mathrm{ab}$ & 2.49 & 0.03 \\
\hline ME (Mcal/kg DM) & 2.72 & 2.67 & 2.71 & 2.67 & 0.03 & 0.51 \\
\hline
\end{tabular}

DMD - dry matter digestibility; OMD - organic matter digestibility; CPD - crude protein digestibility; NDFD - neutral detergent fiber digestibility; ADFD - acid detergent fiber digestibility; EED - ether extract digestibility; ME - metabolizable energy (Mcal/kg DM).

SEM - standard error of the mean.

Means followed by different letters differ statistically by Tukey's test $(\mathrm{P}<0.05)$.

Table 5 - Mean (and standard error) estimate of fecal DM excretion and digestibility coefficients of dietary nutrients determined by different methods

\begin{tabular}{|c|c|c|c|c|c|c|}
\hline \multirow{2}{*}{ Parameter } & \multicolumn{4}{|c|}{ Methods } & \multirow{2}{*}{ SEM } & \multirow{2}{*}{ P-value } \\
\hline & TFC & iNDF & iADF & iADFSeq & & \\
\hline FDME (g/day) & 548.74 & $665.30^{*}$ & $687.54 *$ & $817.49 *$ & 33.71 & 0.006 \\
\hline DMD (0-1) & 0.74 & $0.69 *$ & $0.67 *$ & $0.66^{*}$ & 0.71 & $<0.001$ \\
\hline OMD (0-1) & 0.76 & $0.72 *$ & $0.70 *$ & $0.69 *$ & 0.76 & $<0.001$ \\
\hline $\mathrm{CPD}(0-1)$ & 0.78 & $0.74 *$ & $0.73 *$ & $0.72 *$ & 0.77 & $<0.001$ \\
\hline NDFD (0-1) & 0.67 & $0.62 *$ & $0.60 *$ & $0.58 *$ & 1.02 & $<0.001$ \\
\hline $\operatorname{ADFD}(0-1)$ & 0.62 & $0.56^{*}$ & $0.54 *$ & $0.50 *$ & 1.14 & $<0.001$ \\
\hline $\operatorname{EED}(0-1)$ & 0.73 & $0.66^{*}$ & $0.65^{*}$ & $0.63 *$ & 1.19 & $<0.001$ \\
\hline ME (Mcal/kg DM). & 2.69 & $2.57 *$ & $2.55^{*}$ & $2.51 *$ & 0.02 & $<0.001$ \\
\hline
\end{tabular}

FDME - fecal dry mater excretion; DMD - dry matter digestibility; OMD - organic matter digestibility; CPD - crude protein digestibility; NDFD - neutral detergent fiber digestibility; ADFD - acid detergent fiber digestibility; EED - ether extract digestibility; ME - metabolizable energy.

TFC - total feces collection; iNDF - indigestible neutral detergent fiber; iADF - indigestible acid detergent fiber; iADFSeq - sequentially determined indigestible acid detergen fiber; SEM - standard error of the mean.

* Significantly different from results obtained by the total collection method by Dunnet's test $(\mathrm{P}<0.05)$. 
inclusion of a daily dose of $2.0 \mathrm{~g}$ of freeze-dried propolis extract or monensin sodium per animal. This reduction is probably a result of the broad action spectrum of these products on ruminal microbes (fibrolytic bacteria), since the adopted diet had a high fiber content.

Crude brown propolis promoted higher EE digestibility compared with monensin sodium (Table 4). Oliveira et al. (2007) did not observe any effect of monensin sodium inclusion at $28 \mathrm{mg} / \mathrm{kg} \mathrm{DM}$ in lamb diets with a $65: 35$ roughage:concentrate ratio. Prado et al. (2010) observed a reduction in EE digestibility in cattle supplemented daily with $2.0 \mathrm{~g}$ of freeze-dried propolis extract/animal and attributed this response to the inhibition of rumen-lipolytic microorganisms. Discrepancies between the results of the present study and those obtained by Prado et al. (2010) may be related to methodological differences and the amounts of propolis used.

The increase in EE digestibility may have been due to the rise in EE intake and better adaptation of ruminal microbiota to the substrate, especially Anaerovibrio lipolytica, a rumen bacterium. Lana et al. (2005) found that goat diet supplementation with $10 \mathrm{~mL}$ of propolis extract alone or combined with olive oil does not affect EE digestibility.

Assessment of DM and other nutrient digestibility using the different methods generated varied results. Compared with total feces collection, internal markers underestimated nutrient digestibility (Table 5). These findings were likely a consequence of overestimated fecal DM production by internal markers.

Other studies suggest that iNDF (Véras et al., 2005) and iADF (Alves et al., 2003) are reliable parameters for estimating lamb diet digestibility. However, in another study on lambs, Kozloski et al. (2009) observed that fecal recovery of internal indigestible DM and iNDF markers was not complete and varied considerably among assays. These authors suggest that digestion and/or partial absorption of the markers is a probable cause for this variation, along with physicochemical modifications throughout the digestive tract and deficiencies in analytical procedures.

\section{Conclusions}

Addition of brown propolis has the same effect as monensin, with neither of them maximizing nutrient availability in diets for feedlot lambs at 7 months of age.

Digestibility assessment using the internal markers indigestible neutral detergent fiber, indigestible acid detergent fiber, and sequentially-determined indigestible acid detergent fiber is not an efficient method compared with total feces collection.

\section{Acknowledgments}

This article originated from a research project financed by $\mathrm{CNPq}$ (Conselho Nacional de Desenvolvimento Científico e Tecnológico).

\section{References}

Aderinboye, R. Y.; Onwuka, C. F. I.; Arigbede, O. M.; Oduguwa, O. O. and Aina A. B. 2012. Effect of dietary monensin inclusion on performance, nutrient utilization, rumen volatile fatty acid concentration and blood status of West African dwarf bucks fed with basal diets of forages. Tropical Animal Health and Production 44:1079-1087.

Aguiar, S. C.; Zeoula, L. M.; Franco, L. S.; Peres L. P.; Arcuri P. B. and Forano, E. 2013. Antimicrobial activity of Brazilian propolis extracts against rumen bacteria in vitro. World Journal of Microbiology and Biotechnology 29:1951-1959.

Alves, K. S.; Carvalho, F. F. R.; Véras, A. S. C.; Ferreira, M. A.; Costa, R. G.; Santos, E. P.; Freitas, C. R. G.; Santos Júnior, C. M. and Andrade, D. K. B. 2003. Níveis de energia em dietas para ovinos Santa Inês: Digestibilidade aparente. Revista Brasileira de Zootecnia 32:1962-1968.

AOAC - Association of Official Analytical Chemists. 1997. Official methods of analysis of AOAC International. 16th ed. Gaithersburg, MD, USA.

AOAC - Association of Official Analytical Chemists. 2000. Official methods of analysis of AOAC International. 17th ed. Gaithersburg, MD, USA.

Berchielli, T. T.; Andrade, P. and Furlan, C. L. 2000. Avaliação de indicadores internos em ensaio de digestibilidade. Revista Brasileira de Zootecnia 29:830-833

Brasil. Ministério da Agricultura Pecuária e Abastecimento. 2001. Instrução Normativa n. 3, de 19 de janeiro de 2001. Anexo VI Regulamento técnico para fixação de identidade e qualidade de própolis. Diário Oficial da República Federativa do Brasil, Brasília, DF, 19 jan. 2001.

Choi, Y. M.; Noh, D. O.; Cho, S. Y.; Suh, H. J.; Kim, K. M. and Kim, J. M. 2006. Antioxidant and antimicrobial activities of propolis from several regions of Korea. Food Science and Technoogy 39:756-761.

Deswywysen, A. G.; Ellis, W. C.; Pond, K. R.; Jenkins, W. L. and Connelly, J. 1987. Effects of monensin on voluntary intake, eating and ruminating behavior and ruminal motility in heifers fed corn silage. Journal of Animal Science 64:827-834.

European Pharmacopoeia, 2002. The European Phamacopoeia. 4th ed. Council of Europe, Strasbourg.

Fernandes Júnior, A.; Lopes, M. M. R. L.; Colombari, V.; Monteiro, A. C. M. and Vieira. E. P. 2006. Atividade antimicrobiana de própolis de Apis mellifera obtidas em três regiões do Brasil. Ciência Rural 36:294-297.

Freitas, J. A.; Antonangelo, R. P.; Ribeiro, J. L.; Joslin, M.; Nogueira, S. R. P. and Souza, J. C. 2009. Extrato etanóico de própolis na alimentação de vacas leiteiras. Revista Brasileira de Saúde e Produção Animal 10:333-343.

Funari, C. S. and Ferro, V. O. 2006. Análise de própolis. Ciência e Tecnologia de Alimentos 26:171-178.

Ghisalberti, E. L. 1979. Propolis: a review. Bee World 60:59-84.

Heydari, K. H.; Dabiri, N.; Fayazi, J. and Roshanfekr, H. 2008. Effect of ionophores monensin and lasalocid on performance and carcass characteristics in fattening Arabi lambs. Pakistan Journal of Nutrition 7:81-84. 
Ítavo, C. C. B. F.; Morais, M. G.; Costa, C.; Ítavo, L. C. V.; Franco, G. L.; Silva, J. A. and Reis, F. A. 2011a. Addition of propolis or monensin in the diet: behavior and productivity of lambs in feedlot. Animal Feed Science and Techonology 165:161-166.

Ítavo, C. C. B. F.; Morais, M. G.; Ramos, C. L.; Ítavo, L. C. V.; Tomich, T. R. and Silva, J. A. 2011b. Green propolis extract as additive in the diet for lambs in feedlot. Revista Brasileira de Zootecnia 40:1991-1996.

Kozloski, G. V.; Mesquita, F. R.; Alves, T. P. Castagnino, D. S.; Stefanello, C. M. and Sanchez, L. M. B. 2009. Avaliação do uso de frações indigestíveis do alimento como indicadores internos de digestibilidade em ovinos. Revista Brasileira de Zootecnia 38:1819-1823.

Lana, R. P.; Camardelli, M. M. L.; Queiroz, A. C.; Rodrigues, M. T.; Eifert, E. C.; Miranda, E. N. and Almeida, I. C. C. 2005. Óleo de soja e própolis na alimentação de cabras leiteiras. Revista Brasileira de Zootecnia 34:650-658.

Lana, R. P.; Camardelli, M. M. L.; Rodrigues, M. T.; Eifert, E. C.; Oliveira, M. V. M.; Stradiotti Jr., D. and Oliveira, J. S. 2007. Óleo de soja e própolis na alimentação de cabras leiteiras: consumo de matéria seca e de nutrientes e parâmetros de fermentação ruminal. Revista Brasileira de Zootecnia 36:191-197.

Mirzoeva, O. K.; Grishanin, R. N. and Calder, P. C. 1997. Antimicrobial action of propolis and some of its components: the effects on growth, membrane potential and motility of bacteria. Microbiological Research 152:239-246.

Nagaraja, T. G. and Taylor, M. B. 1987. Susceptibility and resistence of ruminal bacteria to antimicrobial feed additives. Applied Environment Microbiology 53:1620-1625.

NRC - National Research Council. 2000. Nutrient requirements of beef cattle. National Academy Press, Washington, D.C., USA.

NRC - National Research Council. 2007. Nutrient requirements of sheep. National Academy Press, Washington, D.C., USA.

Oliveira, M. V. M.; Lana, R. P.; Eifert, E. C.; Luz, D. F.; Pereira, J. C.; Pérez, J. R. O. and Vargas Jr., F. M. 2007. Influência da monensina sódica no consumo e na digestibilidade de dietas com diferentes teores de proteína para ovinos. Revista Brasileira de Zootecnia 36:643-651.

Ozturk, H.; Pekcan, M.; Sireli, M. and Fidanci, U. R. 2010. Effects of propolis on in vitro rumen microbial fermentation. Ankara Üniversitesi Veteriner Fakültesi Dergisi 57:217-221.
Prado, O. P. P.; Zeoula, L. M.; Moura, L. P. P.; Franco, S. L.; Prado, I. N. and Gomes, H. C. C. 2010. Digestibilidade e parâmetros ruminais de dietas à base de forragem com adição de própolis e monensina sódica para bovinos. Revista Brasileira de Zootecnia 39:1336-1345.

Ríspoli, T. B.; Rodrigues, I. L.; Martins Neto, R. G.; Kazama, R.; Prado, O. P. P.; Zeoula, L. M. and Arcuri, P. B. 2009. Protozoários ciliados do rúmen de bovinos e bubalinos alimentados com dietas suplementadas com monensina ou própolis. Pesquisa Agropecuária Brasileira 44:92-97.

Salles, M. S. V.; Zanetti, M. A.; Titto, E. A. L. and Conti, R.M.C. 2008. Effect of monensin on performance in growing ruminants reared under different environmental temperatures. Animal Feed Science and Technology 147:279-291.

Stelzer, F. S.; Lana, R. P.; Campos, J. M. S.; Mancio, A. B.; Pereira, J. C. and Lima, J. G. 2009. Desempenho de vacas leiteiras recebendo concentrado em diferentes níveis, associado ou não a própolis. Revista Brasileira de Zootecnia 38:1381-1389.

Stradiotti Jr., D.; Queiroz, A. C.; Lana, R. P.; Pacheco, C. G.; Eifert, E. C. and Nunes, P. M. M. 2004a. Ação da própolis sobre a desaminação de aminoácidos e a fermentação ruminal. Revista Brasileira de Zootecnia 33:1086-1092.

Stradiotti Jr., D.; Queiroz, A. C.; Lana, R. P.; Pacheco, C. G.; Camardelli, M. M. L.; Detmann, E.; Eifert, E. C.; Nunes, P. M. M. and Oliveira, M. V. M. 2004b. Ação do extrato de própolis sobre a fermentação in vitro de diferentes alimentos pela técnica de produção de gases. Revista Brasileira de Zootecnia 33:1093-1099.

Van Soest, P. J.; Robertson, J. B. and Lewis, B. A. 1991. Methods for dietary fiber, neutral detergent fiber, and nonstarch polysaccharides in relation to animal nutrition. Journal of Dairy Science 74:3583-3597.

Véras, R. M. L.; Ferreira, M. A.; Véras, A. S. C; Carvalho, F. F. R.; Cavalcanti, C. V. A.; Santos, G. R. A.; Mendonça, S. S.; Soares, C. A. and Sampaio, C. B. 2005. Substituição do milho por farelo de palma forrageira em dietas para ovinos em crescimento. Consumo e digestibilidade. Revista Brasileira de Zootecnia 34:351-356.

Woisky, R. G. and Salantino, A. 1998. Analysis of propolis: some parameters and procedures for chemical quality control. Journal of Apicultural Research 37:99-105.

WHO - World Health Organization. 1998. Quality control methods for medicinal plant materials. World Health Organization, Geneva. 